В. В. Крашановський, судовий експерт, відділу вибухотехнічних та пожежотехнічних досліджень, Луганський науково-дослідний експертнокриміналістичний центр МВС, м. Рубіжне, Луганська обл. ORCID: https://orcid.org/0000-0001-6346-613X

\title{
ПОРІВНЯЛЬНА ХАРАКТЕРИСТИКА РПГ-22 І РПГ-26 3 МЕТОЮ ІДЕНТИФІКАЦІЇ ВИЯВЛЕНИХ ЗАЛИШКІВ НА МІСЦІ ПОДІЇ
}

\begin{abstract}
Meта статті - надати комплексний аналіз теоретичних положень і практичних проблем дослідження частин подібних між собою реактивних протитанкових гранат - РПГ-22 і РПГ-26, у тому числі снарядів ПГ-22 і ПГ-26, які можуть залишатися на місці їх пострілу та подальшого вибуху. Методологія. Достовірність отриманих результатів і висновків забезпечено загальнонауковими (емпіричними та теоретичними) і спеціальними методами дослідження. Так, зокрема, теоретичними загальнонауковими методами дослідження (аналіз, синтез, узагальнення) схарактеризовано наукові та інформаційні джерела за тематикою дослідження, з'ясовано рівень достатності в них профільної інформації для практичного використання. За допомогою емпіричних методів (спостереження, опис тощо) і спеціальних методів дослідження описано параметри та виокремлено особливості залишків деталей реактивних протитанкових гранат і снарядів після вибуху. Порівняльним методом обгрунтовано можливість ідентифікації гранат за їх окремими залишками. Системний підхід до проведення дослідження забезпечив його комплексний характер і дозволив об'єднати окремі результати дослідження (за залишками складових гранат і снарядів) в єдине ціле. Наукова новизна. Виокремлено, описано і унаочнено складові реактивних протитанкових гранат - РПГ-22 та РПГ-26, за залишками яких їх можна ідентифікувати, окреслено розмірні характеристики. Висновки. Визначено розмірні характеристики та конструктивні особливості залишків складових РПГ-22 і РПГ-26, снарядів ПГ-22 і ПГ-26. Обгрунтовано можливість ідентифікації РПГ-22 і РПГ-26 після вибуху за такими основними складовими, як пусковий пристрій (транспортно-пусковий контейнер), чека, задня кришка, елементи вузла кріплення снаряда в пусковому пристрої, а також снарядів ПГ-22 або ПГ-26 за залишками: підривника, корпусу реактивного двигуна, вузла форсування. Здійснено порівняння залишків, результати унаочнено. Сформульовано пропозиції (рекомендації) практико-прикладного характеру з метою уникнути помилок, розв'язуючи питання віднесення досліджуваних гранат і снарядів до тієї чи іншої моделі в межах судової вибухотехнічної експертизи. Ці пропозиції (рекомендації) стануть у пригоді не тільки експертам-вибухотехнікам під час проведення судової вибухотехнічної експертизи, а й іншим працівникам правоохоронних органів під час огляду місця події за фактом вибуху, спричиненого зазначеними вибуховими пристроями, та подальшого досудового розслідування.

Ключові слова: судовий експерт-вибухотехнік; одноразові гранатомети; вибуховий пристрій; ідентифікація залишків; вузол кріплення; реактивний двигун.
\end{abstract}

\section{Вступ}

В Україні останніми роками суттєво збільшилася кількість злочинів, вчинюваних із використанням одноразових реактивних протитанкових гранат, зокрема РПГ-22 i РПГ-26. Великою мірою це пов'язано з подіями на Сході України. А тому судовим експертам важливо досконало знати конструкцію цих пристроїв і умови їх застосування.

За наявності достатньої кількості інформативних залишків вид вибухового пристрою можна визначити під час судової вибухотехнічної експертизи без особливих

(C) В. В. Крашановський, 2020 
проблем. Водночас його тип в межах певного виду розпізнати доволі складно. Проте від цього залежить точність наданих експертних висновків і їх достовірність, а в кінцевому підсумку - досудове розслідування злочинів зазначеної категорії (Metodyka kompleksnoho doslidzhennia, 2005).

Прикладом конструктивно схожих між собою пристроїв $є$ реактивні протитанкові гранати - РПГ-22 і РПГ-26 та снаряди ПГ-22 і ПГ-26, ідентифікація яких за залишками після їх вибуху непросте завдання (Tihonov, 1989).

Звичайно, за наявності транспортно-пускового контейнера з відповідними маркувальними позначеннями визначити той чи інший тип реактивної протитанкової гранати набагато легше. Але, застосовуючи такі боєприпаси, злочинець, як правило, забирає його із собою, приховуючи сліди злочину, а отже ідентифікувати гранату, яка вразила ціль, можна тільки за залишками іï снаряда (Klymenko (Red.), 2005).

Питання ідентифікації залишків конструктивно схожих вибухових пристроїв в різні часи вивчали такі вітчизняні науковці та практики: Н. К. Багдасярян, В. П. Багрій, В. В. Бірюков, О. М. Васін, М. І. Войтенко, В. В. Дралюк, С. Г. Луценко, Ю. П. Приходько, Л. В. Цвик. На пострадянському просторі цю тематику висвітлювали В. М. Базилевич, В. М. Дік, В. В. Кораблін, В. В. Кореньков, О. А. Лові, Є. О. Новіковський, Ф. А. Савченко та ін. Окремі проблеми розглядали, зокрема, Н. С. Венкатесан (N. S. Venkatesan), Р. Огоркевич (R. Ogorkiewicz), мол. Райт (Jr. Wright), К. С. Фрейзер (K. C. Fraser) та ін. (Ogorkiewicz, 1978; Fraser, 1997; Venkatesan, 2014, p. 225-230). Проте далеко не всі аспекти таких ідентифікаційних досліджень здійснено повним обсягом.

Аналіз використовуваних судовими експертами-вибухотехніками джерел, у тому числі інтернет-ресурсів, з описом конструкції та дії зазначених реактивних протитанкових гранат засвідчив брак вичерпної інформації про їх характеристики, насамперед щодо снарядів ПГ-22 і ПГ-26, яка б допомогла експертові ідентифікувати їх за залишками після вибуху. При цьому більшість із них тією чи іншою мірою копіюють інформацію із матеріалів, що донедавна були основними для вибухотехніків (Ryizhkov, 1985; Rukovodstvo po reaktivnoy protivotankovoy granate, 1986). Створені для особового складу сухопутних військ (військовослужбовців, які використовують гранатомети за призначенням, а саме для боротьби з танками, самохідно-артилерійськими установками, іншими броньованими засобами противника), ці джерела корисні і для судових експертів, але в разі, коли РПГ-22 або РПГ-26 надходять для дослідження у транспортному стані. Проте за залишками після вибуху ідентифікувати модель реактивної протитанкової гранати (насамперед снаряда), використовуючи лише ці джерела, неможливо. Доволі складно виокремити індивідуальні відмінності такого снаряда й за наявними схематичними зображеннями РПГ-22 і РПГ-26 (причому повністю скопійованими із зазначених джерел), а також за фотозображеннями залишків снаряда після його вибуху, які без зусиль можна знайти в Інтернеті.

У розробленому Волинським науково-дослідним експертно-криміналістичним центром МВС та виданому в 2019 р. Державним науково-дослідним експертно-криміналістичним центром МВС інформаційному листі про визначення місця пострілу з реактивних протитанкових гранат РПГ-22, РПГ-26 (Matiiuk, 2019) окреслено основні конструктивні елементи гранат РПГ-22 і РПГ-26, які можуть залишатися в зоні місця пострілу, та висвітлено питання визначення цього місця. Проте в цьому документі, зокрема, недостатньо повно схарактеризовано місце вибуху снаряда, бракує докладного опису хвостової частини (реактивного двигуна) снарядів ПГ-22 (РПГ-22) і ПГ-26 (РПГ-26), 
яка практично завжди залишається на місці вибуху та в подальшому є одним з основних об’єктів судової вибухотехнічної експертизи, якісних ілюстрацій та опису вузла кріплення снарядів ПГ-22 і ПГ-26 у пусковому пристрої, залишки якого також можна знайти на місці пострілу, що сприятиме визначенню цього місця та ідентифікації типу гранати.

\section{Мета та завдання дослідження}

Метою статті $є$ комплексний аналіз теоретичних положень і практичних проблем дослідження частин подібних між собою реактивних протитанкових гранат - РПГ-22 і РПГ-26, у тому числі їх снарядів ПГ-22 і ПГ-26, які можуть залишатися на місці їх пострілу та подальшого вибуху.

Для досягнення поставленої мети потрібно вирішити такі завдання:

окреслити розмірні характеристики та конструктивні особливості залишків складових РПГ-22 і РПГ-26 та снарядів ПГ-22 і ПГ-26;

порівняти ці залишки і унаочнити;

сформулювати пропозиції (рекомендації) практико-прикладного характеру з метою уникнути помилок, розв’язуючи питання віднесення їх до тієї чи іншої моделі в межах судової вибухотехнічної експертизи.

\section{Виклад основного матеріалу}

Після виконання пострілу з реактивних протитанкових гранат - РПГ-22 і РПГ-26 на місці пострілу та в безпосередній близькості від нього можуть, засвідчують результати аналізу, залишатися: пусковий пристрій, задня кришка казенного зрізу пускового пристрою (далі - задня кришка), частини вузла кріплення снаряда в пусковому пристрої полімерне кільце, картонний кружок (стосується лише РПГ-22, якщо він не знищується пороховими газами), кришка, герметизувальне кільце, а також чека і залишки вузла форсування реактивного двигуна снаряда. Також на місці вибуху снаряда зазвичай можна знайти залишки його головної частини і власне реактивного двигуна (Dik, 2009a, 2009b).

За наявності пускового пристрою (транспортно-пускового контейнера) ідентифікувати РПГ-22 і РПГ-26 нескладно навіть у разі знищення маркувальних позначень, оскільки конструкції несхожі.

Суттєво розрізняються, насамперед формою і матеріалом виготовлення, й задні кришки пускових пристроїв зазначених гранат (Lutsenko et al.; 2019). Так, у РПГ-22 задня кришка виготовлена з металу, який не притягується полем постійного магніту, вкрита лакофарбовим покриттям оливкового (захисного) кольору, має діаметр 88 мм. Із внутрішнього боку на задню кришку наклеєно гумову прокладку круглої форми діаметром 81 мм, яка виконує роль ущільнювача (рис. 1).

Задня кришка РПГ-26 має діаметр 92 мм, виконана 3 гуми чорного кольору. Характерні вдавлення завглибшки 1 мм утворю-

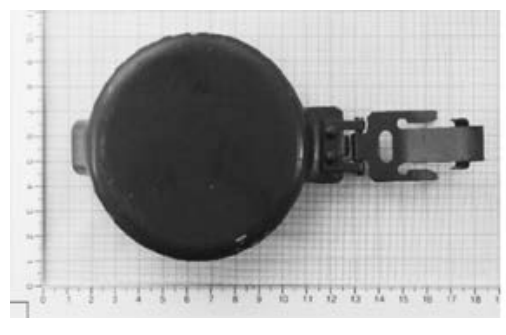

a

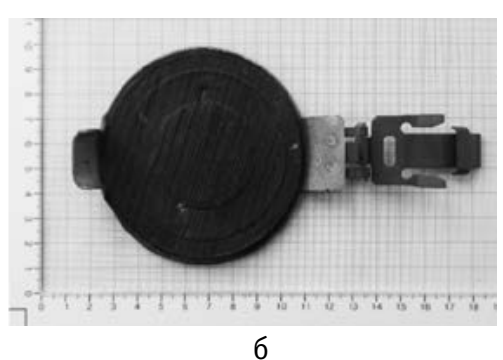

6

Рис. 1. Задня кришка РПГ-22:

а - зовнішній бік; б - внутрішній бік 


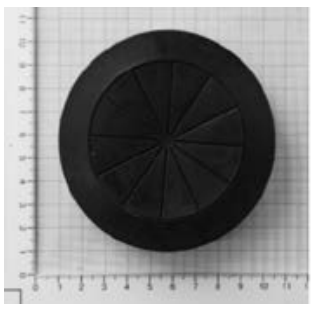

a a - до пострілу; 6 - залишки після пострілу

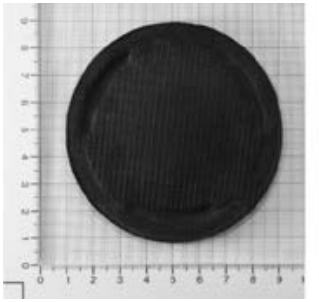

a

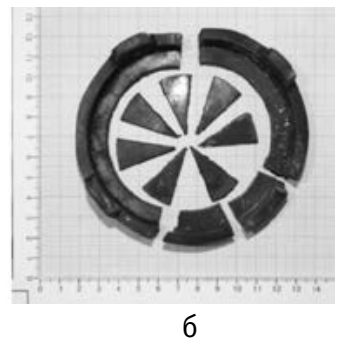

6

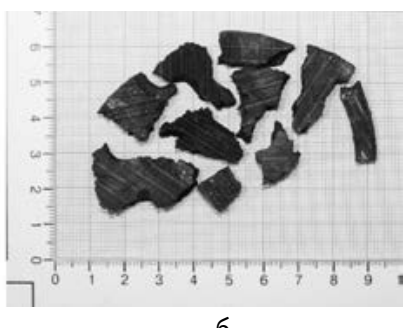

6
Рис. 3. Гумова прокладка РПГ-26: а - до пострілу; б - залишки після пострілу

ють коло діаметром 66 мм, поділене на 12 однакових секторів (рис. 2).

Менша (порівняно з іншими частинами кришки) товщина гуми в місці вдавлення полегшує прорив кришки пороховими газами. Із внутрішнього боку в задню кришку як ущільнювач вставлено гумову прокладку, ідентичну прокладці задньої кришки РПГ-22 (рис. 3).

Під час виконання пострілу із РПГ-26 центральна частина задньої кришки зазвичай повністю проривається в місцях вдавлення, кришка здебільшого зривається зі стяжок, на яких закріплена, та, поділившись на кілька фрагментів, відлітає в бік, протилежний напрямку польоту снаряда (рис. 2). Гумова прокладка із внутрішнього боку задньої кришки розривається на велику кількість фрагментів різних розмірів (рис. 3) (Lovi, Korenkov, Bazilevich, \& Korablin, 2001).

Задні кришки, як і пускові пристрої, в цілому мають важливе значення для розслідування злочинів цієї категорії, зокрема в контексті огляду місця події. Так, виявлення задньої кришки пускового пристрою РПГ-22 може вказувати на місце, з якого безпосередньо виконано постріл, адже в разі переведення гранати з похідного положення в бойове задня кришка від'єднується від пускового пристрою і падає під ноги гранатометника (Dildin, Martyinov, Semenov, \& Shmyirev, 1989).

Для встановлення місця, з якого виконано постріл із РПГ-26, зіставляють місце виявлення задньої кришки і вибуху, проводять між ними умовну лінію, тобто застосовують так званий метод візування (Biriukov, 2013). При цьому беруть до уваги, що під час пострілу як із РПГ-22, так і з РПГ-26 залишки вузла кріплення снаряда та задньої кришки (стосується РПГ-26) відлітають від казенного зрізу пускового пристрою на доволі значну відстань - максимальна, засвідчили полігонні випробування, коли було відстріляно по десять одиниць РПГ-22 і РПГ-26, може становити 62 м (розраховано для рівної місцевості, хоча, безумовно, потрібно зважати на рельєф). На таку саму відстань розлітаються і залишки вузлів форсування обох снарядів.

На місце безпосереднього виконання пострілу може вказувати і наявність чеки 3

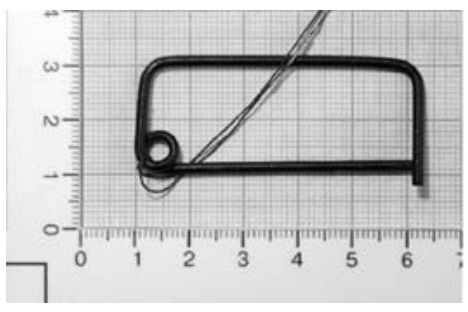

a

Рис. 4. Чека РПГ-22 (а) і чека РПГ-26 (б) огляду на те, що під час переведення РПГ-22 і РПГ-26 у бойове положення чеку як запобіжник витягують із корпусу пускового пристрою, і вона може знаходитися в безпосередній близькості від місця пострілу (рис. 4). 
Ідентифікувати РПГ-22 і РПГ-26 можна й за відмінностями конструкції вузлів кріплення снарядів. Складаються вони: в РПГ-22 - із пластмасового кільця, картонного кружка, кришки та герметизувального кільця (рис. 5, 6 і 7); в РПГ-26 - з пластмасового кільця, кришки та герметизувального кільця (рис. 8, 9 і 10).

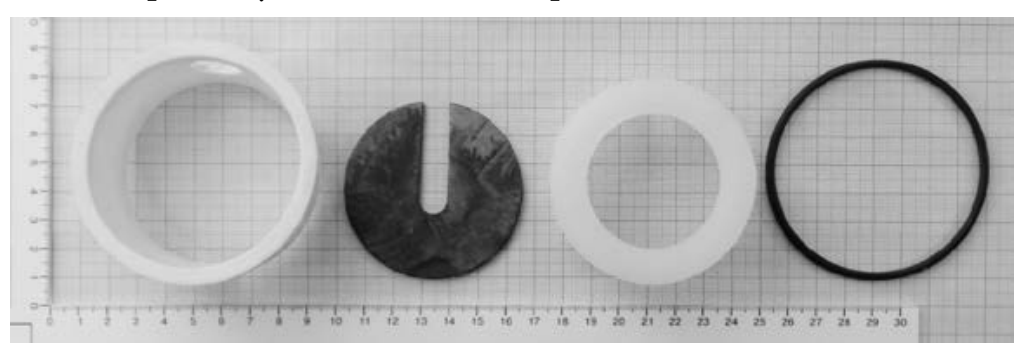

Рис. 5. Вузол кріплення снаряда в РПГ-22 (зліва направо):

пластмасове кільце, картонний кружок, кришка, герметизувальне кільце

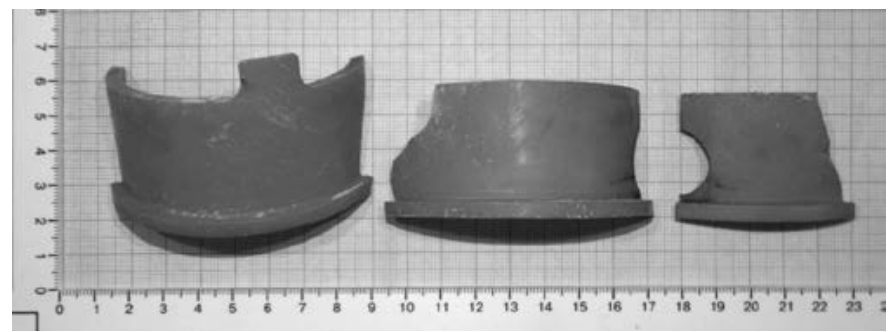

Рис. 6. Залишки пластмасового кільця вузла кріплення снаряда в РПГ-22 після пострілу

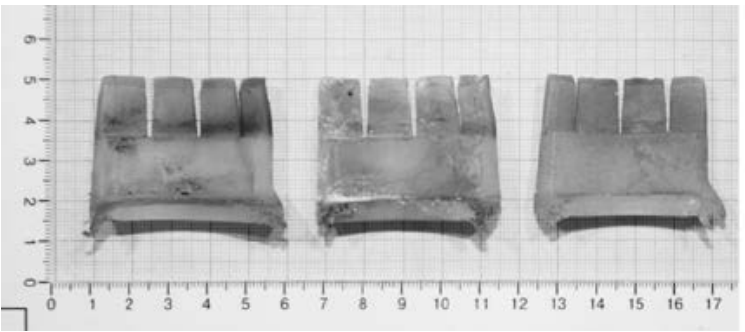

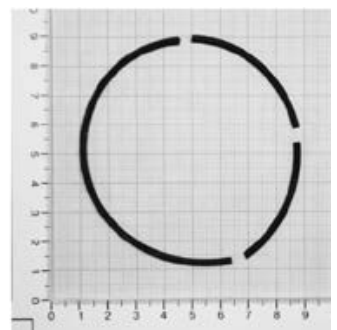

6

Рис. 7. Залишки деталей вузла кріплення снаряда в РПГ-22 після пострілу: а - кришки; 6 - герметизувального кільця

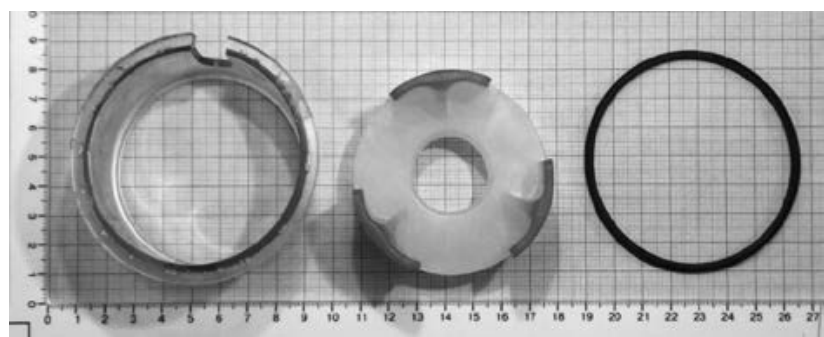

Рис. 8. Вузол кріплення снаряда в РПГ-26 (зліва направо): пластмасове кільце, кришка, герметизувальне кільце 


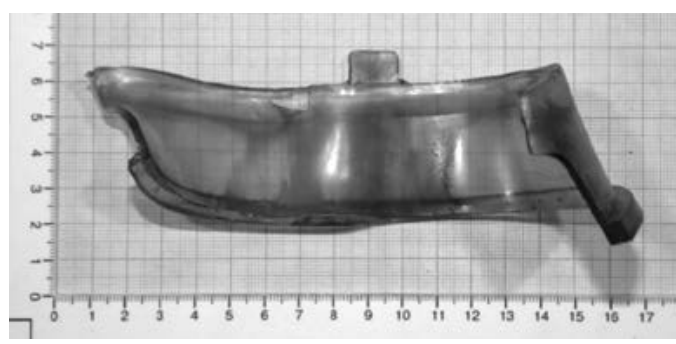

Рис. 9. Залишки пластмасового кільця вузла кріплення снаряда в РПГ-26 після пострілу

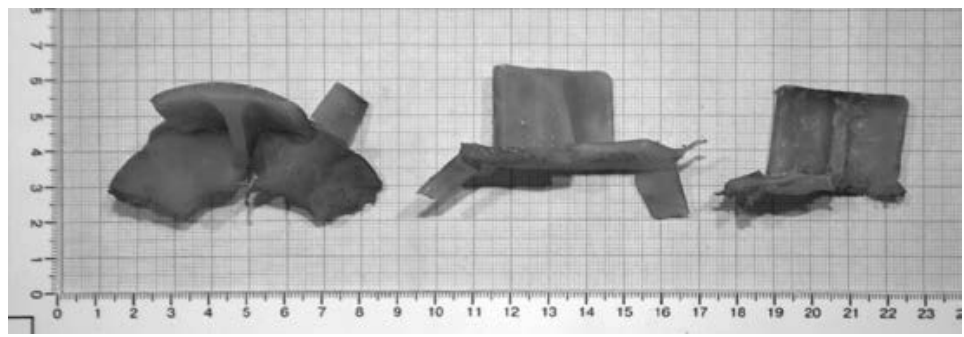

Рис. 10. Залишки кришки вузла кріплення снаряда в РПГ-26 після пострілу

Отже, вузол кріплення снаряда в РПГ-26 повною мірою вдосконалено. При цьому модернізовано конструкції пластмасового кільця і кришки (виготовлене з гуми чорного кольору завтовшки 3 мм герметизувальне кільце залишилося незмінним) (рис. 5 і 8 ). Наприклад, змінилися розміри пластмасового кільця - за однакових діаметрів (71,5 мм у передній і 79 мм у задній частинах) його висота збільшилася до 38,5 мм проти 36 мм в РПГ-22. Крім того, наскрізний отвір, через який проходить газопровідна трубка, набув довгастої форми у вигляді прорізу найбільшою шириною 11 мм (у кільця РПГ-22 отвір має форму кола діаметром 18 мм) (рис. 11).

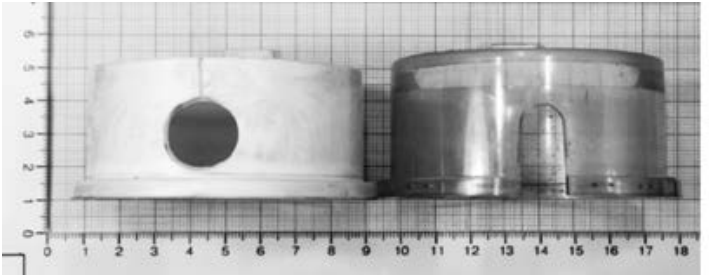

a

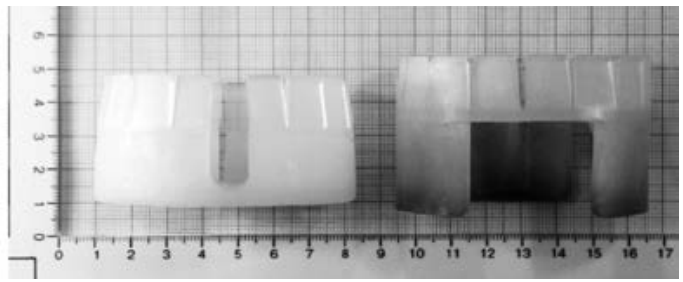

6

Рис. 11. Порівняльні зображення деталей вузлів кріплення снарядів: а - пластмасові кільця; б - кришки (об'єкт ліворуч - РПГ-22, об'єкт праворуч - РПГ-26)

Кришки вузлів кріплення снаряда відрізняються, зокрема, тим, що модернізований їх варіант (РПГ-26) не потребує картонного кружка (рис. 5 і 8).

Кришка в РПГ-22 виготовлена з еластичного полімерного матеріалу, має циліндричну форму (діаметр 68 мм, висота 34 мм). У передній эї частині виконано прорізи заввишки 14 мм, завтовшки від 1 до 1,5 мм кожний, завдяки яким утворено 16 «пелюсток». Також у передній частині кришки наявні один навпроти одного чотири прорізи заввишки 29 мм (три із них завширшки від 1 до 1,5 мм і один - 9,5 мм). У місцях цих порізів кришка руйнується під час пострілу (рис. 7). Усередині кришки два уступи діаметром 57 і 44 мм. Кришку РПГ-26 також виготовлено з еластичного полімерного матеріалу. Вона має 
циліндричну форму (діаметр 66 мм, висота 42,5 мм). У передній ії частині, як і в РПГ-22, виконано прорізи заввишки 14 мм і завтовшки від 1 до 1,5 мм кожний, унаслідок чого утворено 16 «пелюсток», нижні частини яких переходять в пласку поверхню, у середині якої наскрізний отвір діаметром 25 мм. 3 протилежного боку пласкої поверхні наявні рівновіддалені один від одного три виступи заввишки 25 мм і завширшки 33 мм кожний (рис. 11).

Вузол форсування (забезпечує займання порохового заряду), залишки якого дуже часто можна знайти серед залишків вузла кріплення, що в місці з’єднання насадка (сопла) і камери реактивного двигуна снаряда. Складається з полімерного диска та пінопластової заглушки (Savchenko, Shemanaev, Mihalets, \& Partala, 2007). Попри подібність конструкції вузлів форсування в обох типах снарядів, вони мають певні відмінності розмірних по-

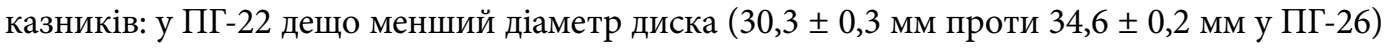
за однакової його товщини $(0,5 \pm 0,2$ мм), менший діаметр заглушки $(22 \pm 1$ мм проти $26 \pm 1$ мм у ПГ-26), менша і товщина заглушки (13 2 мм та $23 \pm 2$ мм відповідно) (рис. 12).

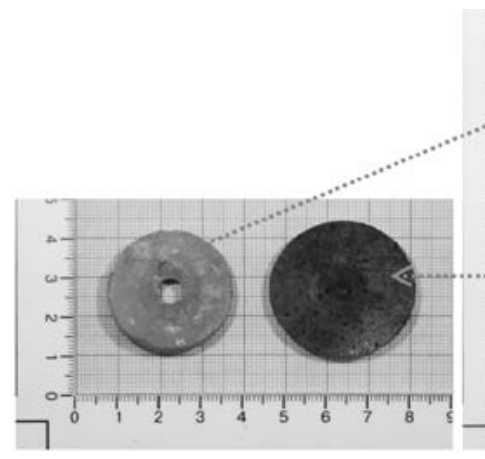

a

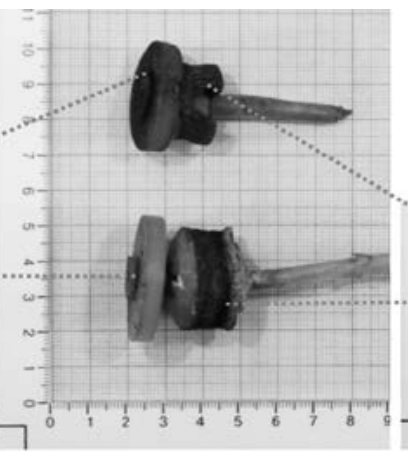

6

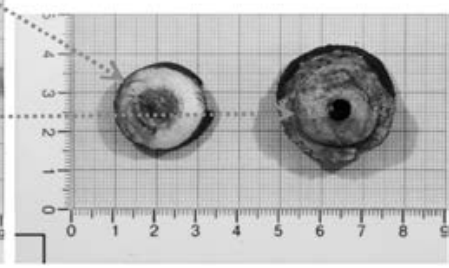

B

Рис. 12. Залишки:

а - диски; б - вузли форсування (зверху в РПГ-22, знизу в РПГ-26); в - заглушки

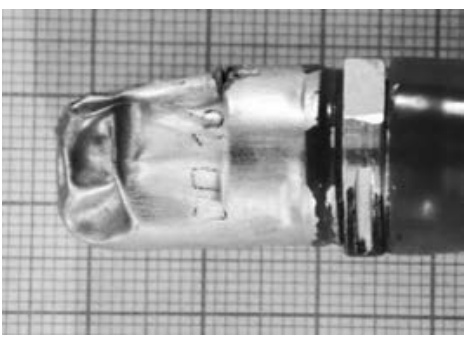

Рис. 13. Головна частина підривника ВП-22 (РПГ-22)

Зазвичай після використання РПГ-22 або РПГ-26 на місці вибуху можна знайти залишки головної частини та реактивного двигуна їх снарядів (Alimpiiev et al., 2015). За залишками головної частини (це, як правило, обтічник) визначити належність снаряда до того чи іншого типу доволі складно, адже інформаційно значущих маркувальних позначень на обтічнику немає, форма та розміри його в обох випадках подібні. Водночас ідентифікувати тип снаряда можна за наявності залишків головної або донної частин підривника завдяки різному маркуванню. Так, снаряд ПГ-22 споряджено головодонним підривником ВП-22, головна частина якого - п’єзогенератор має маркування «ВП-16ГЧ» (рис. 13), а донна - «ВП-22ДЧ» (Ryizhkov, 1985, s. 23). Снаряд ПГ-26 також споряджено головодонним підривником, але марки «7В20», і його головна частина має маркування «ВП-16», а донна - «7В20ДЧ» (рис. 14) (Rukovodstvo po reaktivnoy protivotankovoy granate, 1986, s. 19).

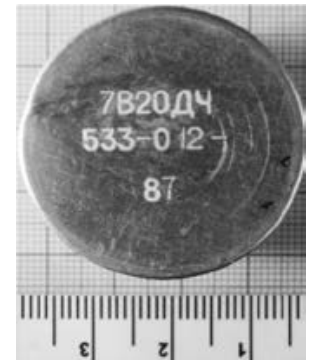

Рис. 14. Донна частина підривника 7В20 (РПГ-26) 
Залишки головної частини снарядів ПГ-22 та ПГ-26 трапляються, засвідчує досвід, украй рідко, в основному коли снаряд змінює траєкторію свого руху внаслідок рикоше-

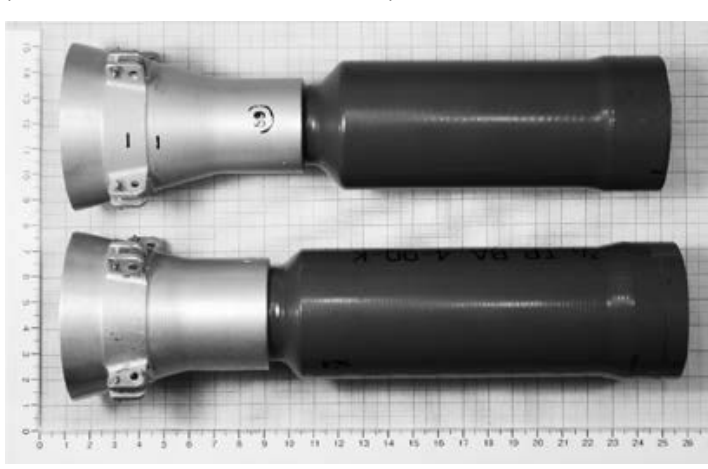

Рис. 15. Порівняльні зображення реактивного двигуна снаряда: ПГ-22 (РПГ-22; об'єкт зверху)

і ПГ-26 (РПГ-26; об'єкт знизу) ту. Донні частини підривника - ще рідше (Novikovskiy, 2009). Водночас майже в кожному випадку на місці вибуху знаходять залишки реактивного двигуна снаряда (рис. 15). Саме вони здебільшого є об'єктом дослідження вибухотехнічної експертизи.

Чітко ідентифікувати реактивний двигун, а за ним і тип гранати можна за його розмірними характеристиками (див., зокрема, табл. і рис. 16, 17).

Основні розмірні характеристики реактивних двигунів снарядів ПГ-22 і ПГ-26

\begin{tabular}{|c|c|c|}
\hline Розмірні характеристики, мм & $\begin{array}{c}\text { ПГ-22 } \\
\text { (РПГ-22) }\end{array}$ & $\begin{array}{c}\text { ПГ-26 } \\
\text { (РПГ-26) }\end{array}$ \\
\hline Загальна довжина (без перехідного дна) & 223,0 & 229,0 \\
\hline \multicolumn{3}{|l|}{ НАСАДОК (СОПЛО) } \\
\hline Загальна довжина насадка & 87,0 & 74,0 \\
\hline Довжина конусоподібної частини насадка & 56,0 & 42,0 \\
\hline Довжина циліндричної частини насадка & 31,0 & 32,0 \\
\hline Діаметр заднього торцевого зрізу насадка & 62,5 & 62,5 \\
\hline Діаметр циліндричної частини насадка & 36,0 & 42,0 \\
\hline $\begin{array}{l}\text { Відстань від заднього торця насадка до початку виступу, на якому } \\
\text { закріплено пір'я }\end{array}$ & 15,5 & 15,5 \\
\hline Довжина виступу, на якому закріплено пір’я & 15,0 & 15,0 \\
\hline \multicolumn{3}{|l|}{ КОРПУС КАМЕРИ ДВИГУНА } \\
\hline $\begin{array}{l}\text { Загальна довжина корпусу реактивного двигуна (від ребра скату вузла } \\
\text { форсування) }\end{array}$ & 121,0 & 143,0 \\
\hline Діаметр корпусу, в якому міститься вузол форсування & 30,0 & 36,0 \\
\hline Діаметр корпусу в центральній частині & 49,0 & 49,0 \\
\hline Діаметр стовщення біля перехідного дна & 52,0 & 52,0 \\
\hline \multicolumn{3}{|l|}{ ПЕРО } \\
\hline Загальна довжина & 94,5 & 94,5 \\
\hline Товщина в місці кріплення & 3,0 & 3,0 \\
\hline Висота в місці кріплення & 8,0 & 8,0 \\
\hline Висота в центральній частині & 10,0 & 10,0 \\
\hline Форма скосу & трикутна & прямокутна \\
\hline
\end{tabular}




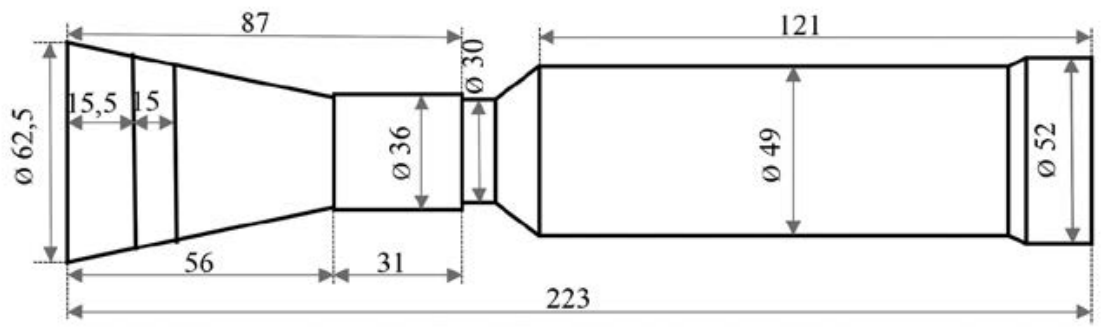

Рис. 16. Схема реактивного двигуна снаряда ПГ-22 (РПГ-22)

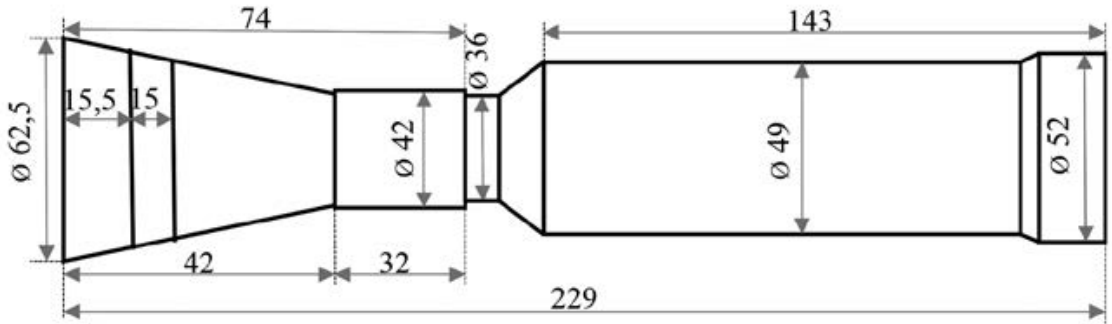

Рис. 17. Схема реактивного двигуна снаряда ПГ-26 (РПГ-26)

Реактивні двигуни обох снарядів складаються з двох основних частин: корпусу камери двигуна та насадка (сопла), до якого шплінтами кріпляться пір'я, призначені для надання гранаті обертання в польоті (рис. 18 і 19).

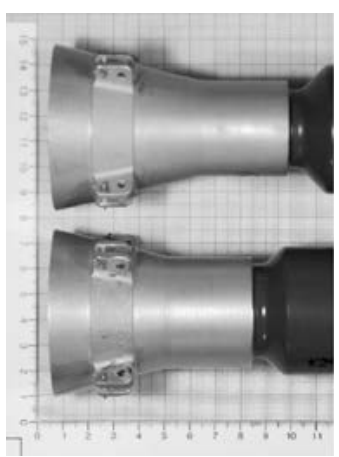

Рис. 18. Насадки реактивних двигунів снарядів: ПГ-22 (РПГ-22) - об'єкт зверху; ПГ-26 (РПГ-26) - об'єкт знизу

Пір'я снарядів ПГ-22 (РПГ-22) і ПГ-26 (РПГ-26) за ідентичних розмірних характеристик та однакової їх кількості (по 4 на кожному насадку) різняться формою (трикутна - ПГ-22 і прямокутна $\left(90^{\circ}\right)$ - ПГ-26) скосу, що на одному боці пера. При цьому чотири пера у снаряда ПГ-26 мають однаковий скіс, а у ПГ-22 - різний: два під кутом $83^{\circ}$ і два $85^{\circ}$ (рис. 20 і 21).

За маркувальними позначеннями, які наносять на поверхню камери реактивного двигуна снаряда чорнилом чорного кольору, ідентифі-

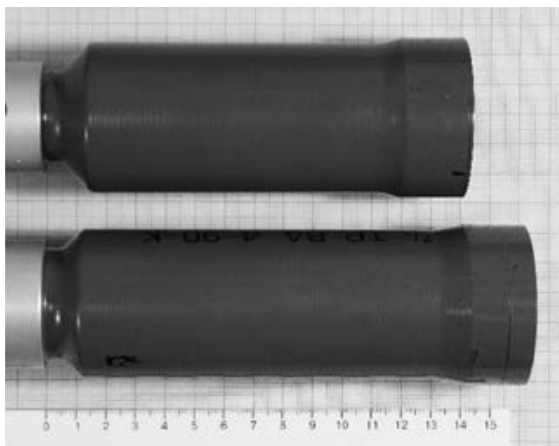

Рис. 19. Корпуси камер реактивних двигунів снарядів: ПГ-22 (РПГ-22) - об'єкт зверху; ПГ-26 (РПГ-26) - об'єкт знизу

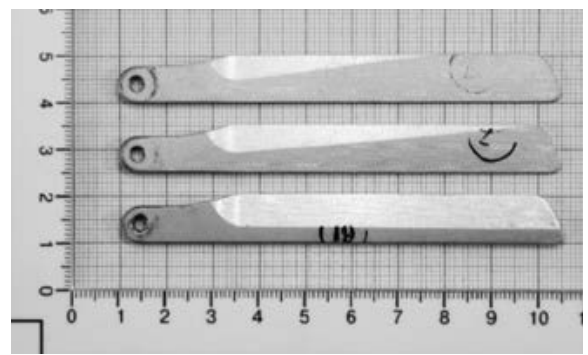

Рис. 20. Порівняльне зображення пір'я реактивних двигунів снарядів:

ПГ-22 (РПГ-22) - два об'єкти зверху; ПГ-26 (РПГ-26) - об'єКТ знизу 


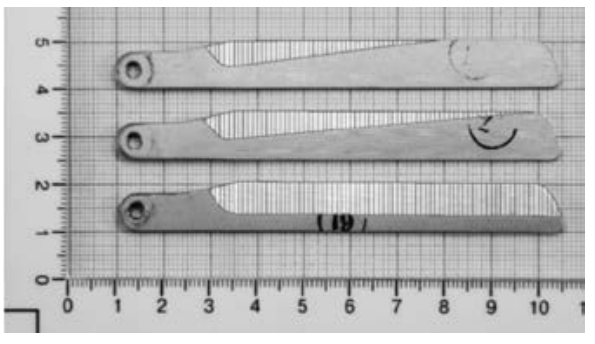

Рис. 21. Зображення пір'я реактивних двигунів снарядів: ПГ-22 (РПГ-22) - два об'єкти зверху; ПГ-26 (РПГ-26) - об'єКт знизу (форма скосів виділена штрихами) кувати його доволі складно через відсутність характерних індивідуальних ознак. За змістом вони здебільшого однакові, a їх шрифт може відрізнятися залежно від заводу-виробника (рис. 22 і 23).

\section{Наукова новизна}

Виокремлено, описано і унаочнено складові реактивних протитанкових гранат - РПГ-22 та РПГ-26, за залишками яких їх можна ідентифікувати, окреслено розмірні характеристики.

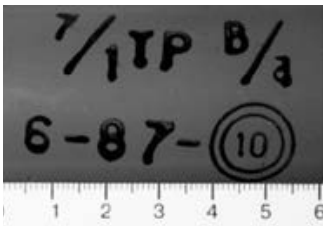

Рис. 22. Маркування на снаряді ПГ-22 (РПГ-22)

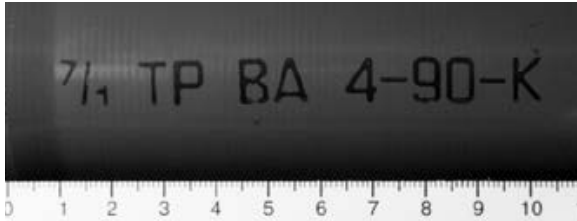

Рис. 23. Маркування на снаряді ПГ-26 (РПГ-26)

\section{Висновки}

1. Окреслено розмірні характеристики та конструктивні особливості залишків складових РПГ-22 і РПГ-26, снарядів ПГ-22 і ПГ-26.

Обгрунтовано можливість ідентифікації РПГ-22 і РПГ-22 після вибуху за такими основними складовими, як пусковий пристрій (транспортно-пусковий контейнер), чека, задня кришка, елементи вузла кріплення снаряда в пусковому пристрої, а також снарядів ПГ-22 або ПГ-26 за залишками: підривника, корпусу реактивного двигуна, вузла форсування.

2. Здійснено порівняння залишків, результати унаочнено.

3. Сформульовано деякі пропозиції (рекомендації) практико-прикладного характеру з метою уникнути помилок, розв'язуючи питання віднесення досліджуваних гранат і снарядів до тієї чи іншої моделі в межах судової вибухотехнічної експертизи. Ці пропозиції (рекомендаціі) стануть у пригоді не тільки експертам-вибухотехнікам під час проведення судової вибухотехнічної експертизи, а й іншим працівникам правоохоронних органів під час огляду місця події за фактом вибуху, спричиненого зазначеними вибуховими пристроями, та подальшого досудового розслідування.

\section{References}

Alimpiiev, A. M., Pievtsov, H. V., Hryb, D. A., Antonov, A. V., Adamenko, A. A., Bzot, A. A. ... Solonets, O. I. (2015). Dovidnyk uchasnyka ATO: ozbroiennia I viiskova tekhnika Zbroinykh syl Rosiiskoi Federatsii: monohrafiia / za zah. red. A. M. Alimpiieva. Kharkiv: Oryhinal. 732 s. [in Ukrainian].

Biriukov, V. V. (2013). Vyznachennia dystantsii postrilu i mistsia, zvidky yoho bulo zdiisneno, za slidamy na mistsi podii. Visnyk Luhanskoho derzhavnoho universytetu vnutrishnikh sprav imeni E. O. Didorenka, 4, 86-92 [in Ukrainian].

Dik, V. N. (2009a). Vzryivchatyie veschestva, poroha i boepripasyi otechestvennogo proizvodstva: spravochnik. Ch. 1. Spravochnyie materialyi. Minsk: Ohotkontakt. 280 s. [in Russian].

Dik, V. N. (2009b). Vzryivchatyie veschestva, poroha i boepripasyi otechestvennogo proizvodstva: spravochnik. Ch. 2. Risunki i illyustratsii. Minsk: Ohotkontakt. 232 s. [in Russian].

Dildin, Yu. M., Martyinov, V. V., Semenov, A. Yu., \& Shmyirev, A. A. (1989). Mesto vzryiva kak ob’ekt kriminalisticheskogo issledovaniya: ucheb. posobie. M.: VNII MVD SSSR. $72 \mathrm{~s}$. [in Russian].

Fraser, K. C. (1997). Anti-tank Weapons. Reference Reviews (Vol. 11 (3), p. 30-34). https://doi.org/10.1108/ rr.1997.11.3.32.198. 
Klymenko, N. I. (Red.). (2005). Ohliad mistsia podii pry rozsliduvanni okremykh vydiv zlochyniv: nauk.-prakt. posib. Kyiv: Yurinkom Inter. $216 \mathrm{~s}$. [in Ukrainian].

Lovi, A. A., Korenkov, V. V., Bazilevich, V. M., \& Korablin, V. V. (2001). Otechestvennye protivotankovye granatometnye kompleksy. Oruzhie. Spetcvypusk. 66 s. [in Russian].

Lutsenko, S. H., Prykhodko, Yu. P., Bahrii, V. P., Vasin, O. M., Draliuk, V. V., Bohdasarian, N. K., Tsvyk, L. V. (2019). Tekhnichni kharakterystyky ta materialna chastyna ruchnykh hranat, hranatometiv i postriliv do $n y k h$ : metod. posib. Kyiv: UkrDHRI. 296 s. [in Ukrainian].

Matiiuk, O. O. (2019). Vyznachennia mistsia postrilu z reaktyvnykh protytankovykh hranat RPH-22, RPH-26: inf. lyst. Kyiv: DNDEKTs MVS Ukrainy. 28 s. [in Ukrainian].

Metodyka kompleksnoho doslidzhennia vybukhovykh prystroiv, vybukhovykh rechovyn i slidiv vybukhu. (2005). Kyiv. 212 s. [in Ukrainian].

Novikovskiy, E. A. (2009). Otechestvennoe strelkovoe oruzhie, granatometyi, ruchnyie oskolochnyie granatyi $i$ boepripasyi. Barnaul: AltGTU. 250 s. [in Russian].

Ogorkiewicz, R. (1978) Tanks and Anti-Tank Weapons. In: Bertram C. (eds) New Conventional Weapons and East-West Security. Studies in International Security. Palgrave Macmillan, London.

Rukovodstvo po reaktivnoy protivotankovoy granate RPG-26. (1986). M.: Voenizdat. 65 s. [in Russian].

Ryizhkov, V. A. (1985). Rukovodstvo po reaktivnoy protivotankovoy granate RPG-22. M.: Voenizdat. 80 s. [in Russian].

Savchenko, F. A., Shemanaev, A. V., Mihalets, S. V., \& Partala, S. V. (2007). Konstruktsiya sredstv porazheniya, boepripasov, vzryivateley i sistem upravleniya sredstvami porazheniya. Konstruktsiya granatometnyih vyistrelov i reaktivnyih granat k granatometam odnorazovogo primeneniya: ucheb. posobie. Penza: PAII. 190 s. [in Russian].

Tihonov, E. N. (1989). Kriminalisticheskaya vzryivotehnika i vzryivotehnicheskaya ekspertiza: metod. rek. Ch. 1. Barnaul: Izdatelstvo AGU. 34 s. [in Russian].

Venkatesan, N. (2014). Recent Developments in Anti-Tank Ammunition. Defence Science Journal, 35 (2), 225 230. Retrieved from https://doi.org/10.14429/dsj.35.6015.

\section{Список використаних джерел}

Алімпієв, А. М., Пєвцов, Г. В., Гриб, Д. А., Антонов, А. В., Адаменко, А. А., Бзот, А. А. ... Солонець, О. І. (2015). Довідник учасника АТО: озброєння і військова техніка Збройних сил Російської Федерації: монографія / за заг. ред. А. М. Алімпієва. Харків: Оригінал. 732 с.

Бірюков, В. В. (2013). Визначення дистанції пострілу і місця, звідки його було здійснено, за слідами на місці події. Вісник Луганського державного університету внутрішніх справ ім. Е. О. Дідоренка, 4, 86-92.

Дик, В. Н. (2009а). Взрывчатые вещества, пороха и боеприпасы отечественного производства: справочник. Ч. 1. Справочные материалы. Минск: Охотконтакт. 280 с.

Дик, В. Н. (2009b). Взрывчатые вещества, пороха и боеприпасы отечественного производства: справочник. Ч. 2. Рисунки и иллюстрации. Минск: Охотконтакт. 232 с.

Дильдин, Ю. М., Мартынов, В. В., Семенов, А. Ю., \& Шмырев, А. А. (1989). Место взрыва как объект криминалистического исследования: учеб. пособие. М.: ВНИИ МВД СССР. 72 с.

Fraser, K. C. (1997). Anti-tank Weapons. Reference Reviews (Vol. 11 (3), p. 30-34). https://doi.org/10.1108/ rr.1997.11.3.32.198.

Клименко, Н. І. (Ред.). (2005). Огляд місия події при розслідуванні окремих видів злочинів: наук.-практ. посіб. Київ: Юрінком Інтер. 216 с.

Лови, А. А., Кореньков, В. В., Базилевич, В. М., \& Кораблин, В. В. (2001). Отечественные противотанковые гранатометные комплексы. Оружие. Спецвыпуск. 66 с.

Луценко, С. Г., Приходько, Ю. П., Багрій, В. П., Васін, О. М., Дралюк, В. В., Богдасарян, Н. К. ... Цвик, Л. В. (2019). Технічні характеристики та матеріальна частина ручних гранат, гранатометів $i$ пострілів до них: метод. посіб. Київ: УкрДГРІ. 296 с.

Матіюк, О. О. (2019). Визначення місия пострілу з реактивних протитанкових гранат РПГ-22, РПГ-26: інф. лист. Київ: ДНДЕКЦ МВС України. 28 с.

Ogorkiewicz, R. (1978) Tanks and Anti-Tank Weapons. In: Bertram C. (eds) New Conventional Weapons and East-West Security. Studies in International Security. Palgrave Macmillan, London.

Методика комплексного дослідження вибухових пристроїв, вибухових речовин і слідів вибуху. (2005).

Київ. 212 с. 
Новиковский, Е. А. (2009). Отечественное стрелковое оружие, гранатометы, ручные осколочные гранаты и боеприпасы. Барнаул: АлтГТУ. 250 с.

Руководство по реактивной противотанковой гранате РПГ-26. (1986). М.: Воениздат. 65 с.

Рыжков, В. А. (1985). Руководство по реактивной противотанковой гранате РПГ-22. М.: Воениздат. $80 \mathrm{c.}$

Савченко, Ф. А., Шеманаев, А. В., Михалец, С. В., \& Партала, С. В. (2007). Конструкция средств поражения, боеприпасов, взрывателей и систем управления средствами поражения. Конструкиия гранатометных выстрелов и реактивных гранат к гранатометам одноразового применения: учеб. пособие. Пенза: ПАИИ. 190 с.

Тихонов, Е. Н. (1989). Криминалистическая взрывотехника и взрывотехническая экспертиза: метод. рек. Ч. 1. Барнаул: Издательство АГУ. 34 с.

Venkatesan, N. (2014). Recent Developments in Anti-Tank Ammunition. Defence Science Journal, 35 (2), 225 230. Retrieved from https://doi.org/10.14429/dsj.35.6015.

Стаття надійшла до редакції 20.11.2019

V. Krashanovskyi, Forensic Expert,

Explosive and Fire Technical Research Department,

Luhansk Scientific Research Forensic Center, MIA of Ukraine,

Rubezhnoye, Lugansk region, Ukraine

\section{COMPARATIVE CHARACTERISTIC OF RPG-22 AND RPG-26 FOR THE IDENTIFICATION OF THE DETECTED REMAINS AT THE SCENE}

The purpose of the article is to analyze the theoretical positions and practical problems of researching parts of similar rocket-propelled anti-tank grenades - RPG-22 and RPG-26, including PG-22 and PG-26 shells, which can remain at the site of their shot and further explosion. Methodology. The reliability of the results and conclusions is provided by general scientific (empirical, theoretical) and special research methods. In particular, general research methods (analysis, synthesis, generalization) made it possible to analyze scientific and information sources on the research topic, to determine the level of sufficiency of relevant information in them for practical use. Using empirical methods (observation, description, etc.) and special research methods, the parameters and features of the remnants of parts of reactive antitank grenades and shells after the explosion are described. The comparative method substantiates the possibility of identifying garnets by their individual residues. A systematic approach to the study provided its comprehensive nature and allowed to combine individual research results (on the remnants of the components of grenades and shells) into a single whole. Scientific novelty. The components of garnets are identified, described and illustrated, by the remains of which they can be identified, dimensional characteristics are indicated. Conclusions. The dimensional characteristics and design features of the residues of the components of RPG-22 and RPG-26, shells PG-22 and PG-26 are determined. The possibility of identifying RPG-22 and RPG-26 after the explosion by such basic components as a launching device (transport and launch container), a check, a back cover, elements of a projectile attachment assembly in a launching device, as well as PG-22 or PG-26 shells is justified for residues: fuse, jet engine housing, forcing unit. A comparison of the residues was carried out, the results are illustrated. Suggestions (recommendations) of a practical and applied nature have been formulated in order to avoid mistakes when the issue of classifying the grenades and shells under study as a model within the framework of a forensic explosion technical examination is being decided. These suggestions (recommendations) will be useful not only to bomb experts in conducting a forensic bomb examination, but also to other law enforcement officials during the inspection of the scene of the incident after the explosion caused by these explosive devices, and further pretrial investigation.

Keywords: forensic expert-explosion engineer; disposable grenade launchers; explosive device; identification of residues; attachment point; jet engine. 
В. В. Крашановский, судебный эксперт

отдела взрывотехнических и пожаротехнических исследований, Луганский научно-исследовательский экспертно-

криминалистический иентр МВД, г. Рубежное, Луганская обл.

\section{СРАВНИТЕЛЬНАЯ ХАРАКТЕРИСТИКА РПГ-22 И РПГ-26 С ЦЕЛЬЮ ИДЕНТИФИКАЦИИ ВЫЯВЛЕННЫХ ОСТАТКОВ НА МЕСТЕ ПРОИСШЕСТВИЯ}

Цель статьи - комплексно проанализировать теоретические положения и практические проблемы исследования частей схожих между собой реактивных противотанковых гранат - РПГ-22 и РПГ-26, в том числе снарядов ПГ-22 и ПГ-26, которые могут оставаться на месте их выстрела и дальнейшего взрыва. Методология. Достоверность полученных результатов и выводов обеспечена общенаучными (эмпирическими, теоретическими) и специальными методами исследования. В частности, теоретические общенаучные методы исследования (анализ, синтез, обобщение) позволили проанализировать научные и информационные источники по тематике исследования, определить уровень достаточности в них профильной информации для практического использования. С помощью эмпирических методов (наблюдение, описание, т. д.) и специальных методов исследования описаны параметры и особенности остатков деталей реактивных противотанковых гранат и снарядов после взрыва. Сравнительным методом обоснована возможность идентификации гранат по их отдельным остаткам. Системный подход к проведению исследования обеспечил его комплексный характер и позволил объединить отдельные результаты исследования (по остаткам составляющих гранат и снарядов) в единое целое. Науиная новизна. Выделены, описаны и проиллюстрированы составляющие гранат, по остаткам которых можно их идентифицировать, обозначены размерные характеристики. Bøıюды. Определены размерные характеристики и конструктивные особенности остатков составляющих РПГ-22 и РПГ-26, снарядов ПГ-22 и ПГ-26. Обоснована возможность идентификации РПГ-22 и РПГ-26 после взрыва по таким основным составляющим, как пусковое устройство (транспортно-пусковой контейнер), чека, задняя крышка, элементы узла крепления снаряда в пусковом устройстве, а также снарядов ПГ-22 или ПГ-26 по остаткам: взрывателя, корпуса реактивного двигателя, узла форсирования. Проведено сравнение остатков, результаты проиллюстрированы. Сформулированы предложения (рекомендации) практико-прикладного характера с целью избежать ошибок, когда решается вопрос отнесения исследуемых гранат и снарядов к той или иной модели в рамках судебной взрывотехнической экспертизы. Эти предложения (рекомендации) будут полезны не только экспертам-взрывотехникам при проведении судебной взрывотехнической экспертизы, но и другим работникам правоохранительных органов во время осмотра места происшествия по факту взрыва, вызванного указанными взрывными устройствами, и дальнейшего досудебного расследования.

Ключевые слова: судебный эксперт-взрывотехник; одноразовые гранатометы; взрывное устройство; идентификация остатков; узел крепления; реактивный двигатель. 